\title{
Real-time web-based microclimate monitoring of broiler chicken trucks on different shifts
}

\author{
Aérica C. Nazareno ${ }^{1}$, Iran J. O. da Silva ${ }^{1}$, Eduardo F. Nunes ${ }^{2}$, Osvaldo Gogliano Sobrinho ${ }^{3}$, \\ Renata M. Marè \& Carlos E. Cugnasca ${ }^{3}$ \\ ${ }^{1}$ Universidade de São Paulo/Escola Superior de Agricultura "Luiz de Queiroz"/Núcleo de Pesquisa em Ambiência. Piracicaba, SP, Brasil. E-mail: \\ aericacn@yahoo.com.br (Corresponding author) - ORCID: 0000-0002-9058-178X; iranoliveira@usp.br - ORCID: 0000-0002-4416-8433 \\ ${ }^{2}$ Centro Universitário Unimetrocamp. Campinas, SP, Brasil. E-mail: eduardo.nunes@unimetrocamp.edu.br - ORCID: 000-0002-3807-5169 \\ ${ }^{3}$ Universidade de São Paulo/Escola Politécnica. São Paulo, SP, Brasil. E-mail: ogogli@usp.br - ORCID: 0000-0002-6381-3450; renata.mare@usp.br - \\ ORCID: 0000-0003-3671-450X; cecugnas@usp.br - ORCID: 0000-0001-8306-9342
}

\begin{abstract}
This research aimed to monitor and evaluate air-conditioned trucks transporting day-old chicks, in various shifts of travel, through general packet radio service (GPRS) technology to provide real-time thermal control for poultry industry managers. The Control-Broilers equipment used were GS-105 and the Monitorar Platform. GS-105 is composed of sensors, a microprocessor, GPRS, and batteries. The Monitorar Platform provided nine applications that acted in coordination with web technology RESTful services. Twenty-eight chick transports were evaluated and monitored using the Control-Broilers. Truck routes were supervised by two researchers to ensure real-time data transmission through laptops and smartphones. Three air-conditioned trucks were used during two of days shifts. The vehicles had the same dimensions, but the routes, travel times, and load densities varied. Measurements of the air temperature, relative humidity, and specific enthalpy inside the trucks were recorded every minute. The experimental design was entirely randomized in a $3 \times 2$ factorial scheme, which represented the three trucks (CL, CA and JA) in two transport shifts (day and night), containing four repetitions (travel). The air-conditioned trucks transporting day-old chicks presented a $92.85 \%$ efficiency for real-time data transmission using GPRS technology. The trucks during the travel shifts did not provide thermal homogeneity in chick loads. The night shift presented worse thermal conditions.
\end{abstract}

Key words: poultry, ambiance, live load, precision animal production, day-old-chicken transport

\section{Monitoramento microclimático via web em tempo real dos caminhões de pintos em diferentes turnos}

\begin{abstract}
RESUMO: O objetivo desta pesquisa foi avaliar e monitorar os caminhões climatizados transportadores de pintos em diversos turnos de viagens, através da tecnologia GPRS (General Packet Radio Service), visando possibilitar um controle térmico em tempo real pelos gestores das indústrias avícolas. $\mathrm{O}$ equipamento Control-Broilers foi composto pelo GS-105 e a Plataforma Monitorar . O GS-105 foi constituído por sensores, microprocessador, GPRS e pilhas. A Plataforma Monitorar ${ }^{\oplus}$ apresentava 9 aplicativos, que atuaram coordenadamente, através da tecnologia web services RESTful. Foram avaliados e monitorados 28 transportes de pintos por meio do Control-Broilers, em um incubatório comercial. Todos os percursos foram supervisionados por dois pesquisadores para assegurar a transmissão dos dados em tempo real, através de computadores portáteis e smartphones. Foram usados três caminhões climatizados, durante dois turnos. Os veículos possuíam as mesmas dimensões, porém, os percursos, tempos de viagens e densidades eram variados. As avaliações temperatura do ar, umidade relativa e entalpia específica dos caminhões fora realizadas em intervalos de um min. $O$ delineamento experimental utilizado foi inteiramente aleatorizado em esquema fatorial $3 \times 2$, que representaram os três caminhões (CL, CA e JA) e os dois turnos (dia e noite), contendo quatro repetições (viagens). Os caminhões climatizados transportadores de pintos proporcionaram $92,85 \%$ de eficiência na transmissão de dados em tempo real, aplicando a tecnologia GPRS. Os caminhões climatizados e os turnos de viagens não apresentaram homogeneidade térmica nas cargas de pintos. O turno da noite foi o que apresentou piores condições térmicas.
\end{abstract}

Palavras-chave: avicultura, ambiência, carga viva, zootecnia de precisão, transporte de pintos de um dia 


\section{INTRODUCTION}

In tropical (hot climate) conditions, it is difficult to maintain the thermal control of air-conditioned trucks transporting broiler chicks because, during day travel, the load of live chicks tends to overheat, leading to hyperthermia. Conversely, during night travel, it tends to cool, leading to hypothermia. Therefore, it is important to consider the air-conditioning efficiency of live load of chicks because trucks are not designed to supply the necessary thermoneutral conditions (Quinn \& Baker, 1997; Nazareno et al., 2015a, 2016). Typically, truck drivers are responsible for the air-conditioning system programming, which is performed inside the steering cab before starting the journey. Nevertheless, during trips, there is no supervision of the thermal conditions.

In agriculture, different sensors networks have been widely used to monitor agricultural environments, such as fields and greenhouses (Ruiz-García et al., 2009). The most efficient technologies and communication protocols have been Wi-Fi (Lopez-Martínez et al., 2018; Luan \& Fan, 2019) and general packet radio service (GPRS). GPRS uses the Global System for Mobile Communications (GSM) to exchange data based on TCP/IP for mobile devices (Vox et al., 2014; Luan \& Fan, 2019). This provides internet access and can be successfully used to send information about a greenhouse to a real-time remote server. However, this type of technology is seldom applied to animal production.

In this sense, the following questions must be answered: does the sealing of the containers of the trucks interfere with the exchange of data in real-time? Is there signal interference in real-time data transmission because of the different shifts and depending on the route of the trucks? Thus, this research aimed to evaluate and monitor air-conditioned trucks transporting day-old chicks in various travel shifts through GPRS technology, with the objective of facilitating real-time thermal control of the loads by poultry industry managers.

\section{Material ANd Methods}

This research was conducted at the Universidade de São Paulo - Escola Superior de Agricultura "Luiz de Queiroz," in partnership with the Universidade de São Paulo - Escola Politécnica and the companies R4F Tecnologia Ltda, Abili Tecnologia da Informação Ltda, and Integradora Flamboiã Ltda.

The Control-Broilers equipment was composed of GS-105 (GPRS and sensors) (R4F Tecnologia, 2014) and the Monitorar Platform (Abili Tecnologia da Informação, 2014), and its development targeted monitoring the microclimate of crops in greenhouses. This type of technological system (GPRS and sensors) for greenhouse monitoring is similar to those developed by Garcia-Sanchez et al. (2011) and Vox et al. (2014). Greenhouses have a constructive topology (metal structures and clear plastic coating) that facilitates the collection and exchange of data to the administrator (Vox et al., 2014; Lopez-Martínez et al., 2018). The same authors reported that this technology was applied at fixed locations inside the greenhouse, and there was no signal interference in the transmission of the collected data.
These technological climate-monitoring systems were not tested in different environments, such as air-conditioned trucks for day-old-chick transportation. Containers of this type of truck are lined with aluminum and expanded polyurethane, completely sealed (Quinn \& Baker, 1997; Nazareno et al., 2015a, 2016). Another important factor concerns the moving of trucks during microclimatic monitoring (traveling to different places), because the performance of the monitoring system during the transport of birds is not known.

To evaluate and monitor, via broiler control, airconditioned trucks transporting chicks in different shifts to facilitate microclimate control inside the containers by realtime administrators, 28 transportation trips were monitored. The travel routes started in a commercial hatchery and ended on the farm. All routes were supervised by a researcher who traveled in the truck cabin with the driver. In addition, another researcher tracked all the truck routes in real-time to ensure the reception of the data. Therefore, the two researchers monitored the same microclimatic tracking of the travel through laptops and smartphones, and any problems related to the reception of data in real-time because of signal interference during the route were visualized by them.

The architecture of the GS-105 equipment consisted of four functional blocks: air temperature sensors (thermistor), air relative humidity (capacitive), microprocessor, gateway GPRS/ cellphone, and a battery pack. The communication system was via radio with the sensor nodes and actuators via GPRS/ cellphone for remote monitoring. It also used wireless sensor network technology in the industrial, scientific, and medical radio frequency band of $915 \mathrm{MHz}$, with radios approved by the Agência Nacional de Telecomunicação (ANATEL). Because the wireless communication sensor nodes were battery-powered, the equipment made the mobility of the sensors possible and did not require infrastructure work for installation. The GS-105 was powered by a power source consisting of eight rechargeable $12 \mathrm{~V}$ nickel-metal hydride batteries with $2700 \mathrm{mAh}$ capacity, which under normal conditions, could provide $12 \mathrm{~h}$ of autonomy. The operating ranges of the sensors (thermistor and capacitive) were temperatures of $-30-80{ }^{\circ} \mathrm{C} \pm 0.3{ }^{\circ} \mathrm{C}$, and $0-100 \% \pm 1.8 \%$ air relative humidity (without condensation). The equipment read the sensor nodes and revised the outputs of the actuator nodes according to the application requirements.

The microprocessor was programmed to record air temperature $\left({ }^{\circ} \mathrm{C}\right)$ readings and air relative humidity $(\%)$ every minute and to calculate the specific enthalpy $\left(\mathrm{kJ} \mathrm{kg}^{-1}\right.$ of dry air) according to the equation proposed by Rodrigues et al. (2011). The data was stored in the equipment until it was transmitted to the server via the gateway GPRS/cellphone (GS-105) in case there was signal interference during the journey. The records of these microclimatic variables on the trucks were transmitted via software to a web server associated with the Monitorar Platform.

The Monitorar Platform monitored the transport containers by a network of suitable sensors. The GS-105 transmitted the acquired data continuously to a web server on which data were stored and processed. The data were available to authorized users (administrators) through an interface accessible by a typical web browser. These data were displayed in a variety of 
ways, such as graphs of dashboards of instantaneous values and spreadsheets. Administrators received critical values of temperature, air relative humidity, and specific enthalpy by the Short Message Service of cellular telephony and email.

In the simplified architecture of the Monitorar Platform, a set of nine applications worked in a coordinated manner (Figure 1). The exchange of data between the applications occurred through the RESTful technology web services, as described by Pautasso et al. (2014), which provided small data packets - an important feature in a system with a large amount of information exchange.

The Control-Broilers equipment was tested in a broiler

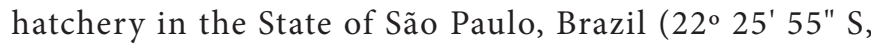
$46^{\circ} 57^{\prime} 28^{\prime \prime} \mathrm{W}$; atmospheric pressure of $762 \mathrm{mmHg}$ at $632 \mathrm{~m}$ ). The experimental periods were three months during spring and summer, with 28 transports of day-old chicks monitored, with trajectories ranging from 106 to $320 \mathrm{~km}$, travel time of 2-6 h and densities of 400-590 boxes/transport of birds. These loads of chicks were evaluated in two shifts (day $=11-18 \mathrm{~h}$ and night $=22-6 \mathrm{~h}$ ), according to the transport logistics of the company. According to Nazareno et al. (2015a, 2015b) the transport logistics of commercial poultry hatcheries occurs according to the supply and demand of the company, therefore the density of cargo can exceed 600 boxes/transport of birds.

For the 28 trips, three types of air-conditioned Volkswagen trucks were used $(\mathrm{CL}=$ Constellation 15.190 Advantech Dibracam, CA = Constellation 13.190 Advantech Dibracam e JA = Constellation 13-180 Dibracam), presenting the same dimensions of containers $(8.00 \times 2.60 \times 2.50 \mathrm{~m})$ and with two axles. The literature comments on the lack of standardization of air-conditioned trucks, even if these are equal in dimensions of containers, brands, models, etc. were the same (Quinn \& Baker, 1997; Nazareno et al., 2015a, b). Therefore, GS-105 and Monitorar Platform were tested in three trucks with similar brands, models, numbers of axles, container dimensions and air conditioning systems, in order to verify the collection and real time data transmission.

The experimental design adopted to evaluate and monitor the efficiency of Control-Broilers was entirely randomized $3 \times 2$ factorial scheme, which represented the three trucks (CL, CA and JA), in two transport shifts (day and night), containing four repetitions (travel or transport of chicks).

All containers of the air-conditioned trucks were lined internally and externally with aluminum, with thermal

\begin{tabular}{|c|c|c|}
\hline $\begin{array}{l}\text { Interface } \\
\text { Generator }\end{array}$ & $\begin{array}{l}\text { Administrative } \\
\text { Module }\end{array}$ & $\begin{array}{c}\text { Authentication of } \\
\text { User }\end{array}$ \\
\hline \multirow{3}{*}{ Alarms } & \multicolumn{2}{|c|}{ DBMS } \\
\hline & \multicolumn{2}{|c|}{ Data Management Module } \\
\hline & \multicolumn{2}{|c|}{ Primary Gateways } \\
\hline $\begin{array}{c}\text { Main } \\
\text { Gateway }\end{array}$ & $\begin{array}{l}\text { Secu } \\
\text { Prim } \\
\text { Gate }\end{array}$ & $\begin{array}{c}\text { Web Direct } \\
\text { Access }\end{array}$ \\
\hline
\end{tabular}

Figure 1. Monitorar Platform: simplified architecture insulation of expanded polyurethane. The doors were constructed with three layers of stainless steel and full sealing. In the interior, there were three rows (left lateral, right lateral and central), with a $0.70 \mathrm{~m}$ of spacing. Longitudinally, the sides were divided by two shelves, with a vertical spacing of approximately $0.81 \mathrm{~m}$ between them. All electrical parts and the air-conditioning system (sensors) of the truck containers were embedded internally between fully enclosed (internal and external aluminum) linings. Therefore, there was no possibility of connecting any electronic and technological devices to the internal air-conditioning system of the chick containers.

The air-conditioning system of the trucks was provided for internal temperature, ventilation, and humidity. These were controlled by sensors and humidifiers (centrifugal or nozzle of pressurized air) located inside the containers. The control was achieved by using a digital electronic system located in the truck cabin; therefore, the microclimatic adjustment was altered manually and depended on the driver to program the electronic system. The thermal control was programmed for the following conditions: temperature of $23-25{ }^{\circ} \mathrm{C}$ and air relative humidity between 60 and $70 \%$. The scheduling of the thermal conditions of the containers was carried out before the start of the trips. Furthermore, during journeys, there was no inspection or adjustment of the thermal conditions of the transported cargo. Therefore, it was verified that during journeys the microclimates of the containers did not have adequate transport conditions. This can be verified in the results of this research.

The air-conditioning system of the trucks was located in front of the containers, part of the air circulation was distributed through the openings of the floor, and the air vents were located in openings on the roof. The air-conditioning system was only activated when the truck was in motion.

The boxes used for the day-old chicks transport had a total capacity of 100 chicks/box and the following dimensions: $42 \mathrm{~cm}$ wide, $57 \mathrm{~cm}$ long, and $15 \mathrm{~cm}$ high, with a $2.5 \mathrm{~mm}$ of thickness. These boxes had 26 openings each, with a $1 \mathrm{~cm}$ width and a 6.5 $\mathrm{cm}$ height around them. Under normal transport conditions, the boxes were stacked, and the first box of each stack received a perforated cover to facilitate the minimum circulation of air to the animals during trips.

The Control-Broilers was installed in the geometric center of the cargo container since according to Quinn \& Baker (1997) and Nazareno et al. (2015a, b), this region has the lowest thermal heterogeneity for this type of live load (Figure 2). Because the containers of the trucks were completely closed, it was not possible to make any equipment adaptation to register the microclimate of the external environment of the containers during transportation.

The microclimatic evaluations of the trucks were performed at one minute intervals during transportation, by recording the air temperature $\left(\mathrm{T},{ }^{\circ} \mathrm{C}\right)$ and air relative humidity $(\mathrm{RH}, \%)$. The values of air temperature, air relative humidity and mean local atmospheric pressure $(761.98 \mathrm{mmHg})$ were used to calculate the specific enthalpy ( $\mathrm{h}, \mathrm{kJ} \mathrm{kg}^{-1}$ of dry air), using equation proposed by Rodrigues et al. (2011).

All variables ( $\mathrm{T}, \mathrm{RH}$ and $\mathrm{h}$ ) were investigated through analysis of variance, which considered the classical linear 
A.

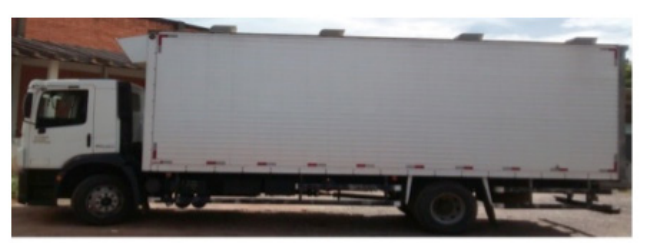

B.

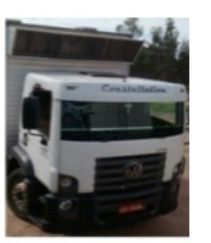

C.

D.

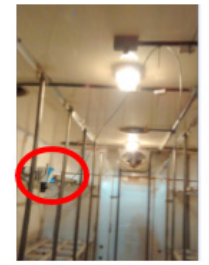

E.

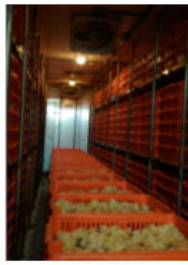

F.

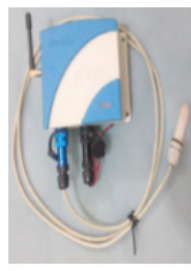

Figure 2. Lateral and frontal images of the truck (A and B), Control-Broilers equipment and installation $(\mathrm{C}$ and $\mathrm{D})$, and internal profile of chick load (E and F)

model of fixed effects, and their assumptions were validated from residue graphs, the Shapiro-Wilk normality tests, and the Hartley's homogeneity of variance. Treatments were compared using a Tukey test at $\mathrm{p} \leq 0.05$. All analyses were performed using the SAS Institute (2010) statistical package.

\section{Results AND Discussion}

Based on the functionality (real-time data collection and transmission for administrators) of the Control-Broilers equipment, it was verified that, during the 28 transports of day-old chicks, the data records could not be transmitted in real time in only two trips. Nevertheless, these data records were stored in the equipment for a period of $1 \mathrm{~h}$ during the two trips. After this failure of real-time data transmission because of the lack of signal coverage by telephone operator, the signal was restored, and the data were retransmitted. Thus, ControlBroilers had a $92.85 \%$ data transmission efficiency using GPRS technology in air-conditioned trucks.

The Control-Broilers equipment experienced a delay in data transmission twice owing to problems in the GSM. According to Garcia-Sanchez et al. (2011) and Luan \& Fan (2019), this was expected, because the GRPS requires a signal from the telephone operator company to transmit the data in real time. In Brazil, there are still places where the signals from mobile operators are weak inoperant (Souza et al., 2015; Agência Nacional de Telecomunicação, 2017). By observing the reliability of the communication network, Garcia-Sanchez et al. (2011) noticed that the system showed $0.3 \%$ lost or incorrectly transmitted data, and $2 \%$ of the messages were lost during communication between the greenhouse and the server that performed the data collection.

According to these results, the air-conditioned trucks transporting day-old chicks had a $92.85 \%$ efficiency in the data transmission using the GRPS technology. The constructive topology of the truck containers was not an obstacle to transmitting data, even in motion.

For the interaction between the air-conditioned trucks and shifts and the air temperature in the transport of day-old chicks, it was observed that there was difference $(\mathrm{p}<0.0001)$ (Table 1). The CA truck during day shifts differed from JA truck, and the latter did not differ from CL truck. However, in the night shifts, the CA truck differed from CL, and the latter did not differ from JA truck. When evaluating only the transportation shifts of these trucks, it was observed that day shift differed significantly from the night shift in all trucks. The highest mean air temperature observed was in the CA truck and day shift $\left(30.21^{\circ} \mathrm{C}\right)$.

As expected, even with the similarity between brands and models of air-conditioned trucks, there was an air temperature variation of approximately $2{ }^{\circ} \mathrm{C}$ (Table 1$)$. These results are in conformity with those of Quinn \& Baker (1997), who reported the lack of standardization in the construction of containers. The containers were manufactured without following the same standard; therefore, the adaptations were made for each type of cargo, which causes thermal heterogeneity in the load profile (Nazareno et al., 2015a). Although the types of live transport vehicles and loads (swine, cattle, horses, poultry and goats) in their research were different from those evaluated in this study, Schwartzkopf-Genswein et al. (2012) and Barbosa Filho et al. (2014) also reported the difficulty in improving the thermal heterogeneity in the transport of these animals because of the lack of truck standardization.

The air-conditioned trucks carrying chicks presented difficulty in maintaining a constant internal temperature of the containers during the shifts, and day shifts presented the highest temperature in all trucks.

Based on the thermal comfort range of day-old chicks (32$35^{\circ} \mathrm{C}$ ) established by Mujahid \& Furuse (2009) and Vieira et al. (2019) and the mean thermal gradient of $4{ }^{\circ} \mathrm{C}$ (temperature difference of the container environment and interior of the chick boxes) in the air-conditioned trucks used to transport these birds, all the vehicles in day shift were within the range of comfort, because the average internal temperatures of the boxes were estimated $34.21,32.63$ and $32.51{ }^{\circ} \mathrm{C}$, respectively, for the CL, CA and JA trucks. However, trucks during night shifts were below the comfort temperature range at 30.00, 28.21 and $28^{\circ} \mathrm{C}$, respectively. Air temperatures above the ideal range for birds can induce hyperthermia with dehydration, leading to a reduction in feed consumption and in growth delay. Furthermore, temperatures below the ideal range can trigger

Table 1. Mean air temperature and standard deviation in different trucks and shifts during transportation of live load of chicks

\begin{tabular}{|c|c|c|}
\hline \multirow[t]{2}{*}{ Trucks } & \multicolumn{2}{|c|}{$\begin{array}{l}\text { Mean air temperature }\left({ }^{\circ} \mathbf{C}\right) \text { and the standard } \\
\text { deviation in the shifits }\end{array}$} \\
\hline & Day & Night \\
\hline$C L$ & $28.51 \mathrm{bA} \pm 0.86$ & $24.21 \mathrm{bB} \pm 2.00$ \\
\hline $\mathrm{CA}$ & $30.21 \mathrm{aA} \pm 1.77$ & $26.00 \mathrm{aB} \pm 1.86$ \\
\hline $\mathrm{JA}$ & $28.63 \mathrm{bA} \pm 3.23$ & $24.00 \mathrm{bB} \pm 2.23$ \\
\hline DF Residue & \multicolumn{2}{|c|}{4423} \\
\hline F-Test & \multicolumn{2}{|c|}{1031.08} \\
\hline $\mathrm{p}$ & \multicolumn{2}{|c|}{$<0.0001^{*}$} \\
\hline CV $(\%)$ & \multicolumn{2}{|c|}{8.01} \\
\hline
\end{tabular}

CL - Constellation 15.190 Advantech Dibracam; CA - Constellation 13.190 Advantech Dibracam; JA - Constellation 13-180 Dibracam; DF - degrees of freedom; CV - coefficient of variation; Means following by the same letter (lowercase letter in columns and uppercase letters in lines) do not differ statistically at $\mathrm{p} \leq 0.05$ between themselves according to the Tukey test; ${ }^{*}$ - Significant at $\mathrm{p} \leq 0.05$ 
hypothermic conditions and induce pulmonary hypertension syndrome (ascites) in broilers (Cassuce et al., 2013).

There was a significant difference ( $\mathrm{p} \leq 0.0001)$ between airconditioned trucks, shifts and the air relative humidity during journeys (Table 2). The JA, CL and CA trucks during day shifts differed. Moreover, during the night shift, the JA, CA and CL trucks differed significantly. When checking the travel shifts of the trucks, night shifts differed from day shifts for all trucks. The highest mean air relative humidity was observed in the JA truck at night shift (74.13\%).

The air relative humidity of the transporter containers of chicks and the travel shifts had a variation of $22.71 \%$, which, according to Quinn \& Baker (1997), can be attributed to the low efficiency of the air circulation system, the dismantling of the vehicles, and the variation of load density.

The poultry companies use the system of wetting the containers before loading the day-old chicks. This procedure is executed in the two shifts without any thermal monitoring of the transportation environment. Companies believe that by increasing the internal air relative humidity of the airconditioned container, this would provide higher internal control of temperature and humidity. Despite using different trucks, loads and load densities, in the pre-slaughtering of broilers, the industry wets the cargo (poultry) before trips. This practice is performed without the monitoring of thermal conditions (Vieira et al., 2011; Barbosa Filho et al., 2014). However, these practices require supervised thermal conditions during shipments to avoid increasing the air relative humidity without necessity.

For the night shift, it was verified that the air relative humidity was above the recommended ranges (50\%-60\%) for the three trucks according to Quinn \& Baker (1997), Mujahid \& Furuse (2009), Nazareno et al. (2015a) and Vieira et al. (2019). Because this variable acts directly on the heat exchanges (sensitive and latent) of chicks (Vieira et al., 2019), these birds tend to have difficulty in thermal exchange. Evaporative (latent) heat loss increases with temperature; however, it decreases with increasing air relative humidity, and its participation in the thermoregulation of the bird depends on the air temperature and the age of the bird (Cassuce et al., 2013; Vieira et al., 2019).

When the air relative humidity is more than $60 \%$, birds reduce heat transfer from the inner parts of the body to the periphery, which impairs heat exchange with the environment

Table 2. Mean air relative humidity and standard deviation in different trucks and shifts during live load transportation

\begin{tabular}{|c|c|c|}
\hline \multirow[t]{2}{*}{ Trucks } & \multicolumn{2}{|c|}{$\begin{array}{l}\text { Mean air relative humidity (\%) and the } \\
\text { standard deviation in the shifts }\end{array}$} \\
\hline & Day & Night \\
\hline CL & $54.79 \mathrm{bB} \pm 7.67$ & $68.89 \mathrm{cA} \pm 7.63$ \\
\hline CA & $51.42 \mathrm{cB} \pm 5.05$ & $70.41 b A \pm 8.32$ \\
\hline JA & $56.74 \mathrm{aB} \pm 10.48$ & $74.13 \mathrm{aA} \pm 5.81$ \\
\hline DF Residue & \multicolumn{2}{|c|}{4423} \\
\hline F-Test & \multicolumn{2}{|c|}{1075.64} \\
\hline$p$ & \multicolumn{2}{|c|}{$<0.0001^{*}$} \\
\hline CV (\%) & \multicolumn{2}{|c|}{11.53} \\
\hline \multicolumn{3}{|c|}{$\begin{array}{l}\text { CL - Constellation } 15.190 \text { Advantech Dibracam; CA-Constellation } 13.190 \text { Advantech } \\
\text { Dibracam; JA - Constellation 13-180 Dibracam; DF - degrees of freedom; CV - coefficient } \\
\text { of variation; Means following the same letter (lowercase letter in columns and uppercase } \\
\text { letters in lines) do not differ statistically at } \mathrm{p} \leq 0.05 \text { between themselves according to the } \\
\text { Tukey test; }{ }^{*} \text { - Significant at } \mathrm{p} \leq 0.05\end{array}$} \\
\hline
\end{tabular}

(Mujahid \& Furuse, 2009; Vieira et al., 2019). However, when the air relative humidity is less than $50 \%$, the heat exchanges between the animal and the latent container environment are high (Mujahid \& Furuse, 2009; Cassuce et al., 2013). Low air relative humidity can cause ascitic syndrome and dehydration of the mucous membranes of chicks in the first weeks of life.

In relation to the specific enthalpy, there was a difference $(\mathrm{p} \leq 0.0001)$ in the interaction between air-conditioned trucks and shifts during the transport of chicks (Table 3 ). The CA, JA and CL trucks differed significantly in day and night shifts. In addition, all truck shifts differed. The highest mean value of specific enthalpy occurred in the CA truck and in day shifts $\left(65.08 \mathrm{~kJ} \mathrm{~kg}^{-1}\right.$ of dry air). The specific enthalpy of the air-conditioned trucks and shifts had a variation of $7.99 \mathrm{~kJ} \mathrm{~kg}^{-1}$ of dry air. This was attributed to the oscillation of air temperature and air relative humidity in the interior of the containers (Table 3 ).

Considering the ideal ranges of air temperature and air relative humidity of the container $\left(32^{\circ} \mathrm{C}-35^{\circ} \mathrm{C}\right.$ and $\left.50 \%-60 \%\right)$ established by Quinn \& Baker (1997), Mujahid \& Furuse (2009), Nazareno et al. (2015a), and Vieira et al. (2019), with a local mean atmospheric pressure of $761.98 \mathrm{mmHg}$, it can be stated that the specific enthalpy of the container environment was below the recommended ranges $\left(69.45-88.19 \mathrm{~kJ} \mathrm{~kg}^{-1}\right.$ of dry air) for day-old chicks. The lower the enthalpy value, the lower is the amount of thermal energy in the dry air (truck container) (Çengel \& Boles, 2001). Thus, the birds experience difficulties in storing and dissipating heat during transportation.

These results demonstrate that there is a necessity to improve the air-conditioning standards of trucks that transport day-old chicks, because, even though it was a totally closed and air-conditioned environment, there was a greater homogeneity in the microclimatic characteristics of the containers on the trucks.

Table 3. Mean specific enthalpy and standard deviation in different trucks and shifts during live load transportation

\begin{tabular}{|c|c|c|}
\hline \multirow[t]{2}{*}{ Trucks } & \multicolumn{2}{|c|}{$\begin{array}{l}\text { Mean specific enthalpy ( } \mathrm{kJ} \mathrm{kg}^{-1} \text { of dry air) } \\
\text { and the standard deviation in the shifts }\end{array}$} \\
\hline & Day & Night \\
\hline $\mathrm{CL}$ & $62.00 \mathrm{cA} \pm 4.47$ & $57.09 \mathrm{cB} \pm 7.37$ \\
\hline CA & $65.08 \mathrm{aA} \pm 5.81$ & $62.78 \mathrm{aB} \pm 3.42$ \\
\hline $\mathrm{JA}$ & $63.19 b A \pm 6.11$ & $58.76 \mathrm{bB} \pm 7.08$ \\
\hline DF Residue & \multicolumn{2}{|c|}{4423} \\
\hline F-Test & \multicolumn{2}{|c|}{189.87} \\
\hline p & \multicolumn{2}{|c|}{$<0.0001 *$} \\
\hline CV $(\%)$ & \multicolumn{2}{|c|}{9.80} \\
\hline
\end{tabular}

CL - Constellation 15.190 Advantech Dibracam; CA - Constellation 13.190 Advantech Dibracam; JA - Constellation 13-180 Dibracam; DF - degree of freedom; CV - coefficient of variation; Means following the same letter (lowercase letter in columns and uppercase letters in lines) do not differ statistically at $\mathrm{p} \leq 0.05$ between themselves according to the Tukey test; ${ }^{*}$ - Significant at $\mathrm{p} \leq 0.05$

\section{Conclusions}

1. The chick conveyor trucks demonstrated a $92.85 \%$ efficiency in data transmission when GPRS technology was applied.

2. The air-conditioned trucks and the travel shifts did not show thermal homogeneity in the chick loads.

3. The night shift had worse thermal conditions for the transportation of chicks. 


\section{ACKNOWLEDGEMENTS}

The authors thank Conselho Nacional de Desenvolvimento Científico e Tecnológico (CNPq, Brazil) for granting a scholarship, and the Fundação de Amparo à Pesquisa do Estado de São Paulo (FAPESP) and the Financiadora de Estudos e Projetos (FINEP) for their support on the Monitorar project (2013/50085-2). We would like to thank Editage (www.editage. com) for the English language editing.

\section{Literature Cited}

Abili Tecnologia da Informação. Plataforma monitorar, 2014. Available on: <http://www.abili.com.br/sistemas-baseados-emweb/sistemas-para-o-agronegocio/>. Accessed on: Nov. 2018.

Agência Nacional de Telecomunicação. Relatório anual de serviços móveis, dados e satélite. 2017. Available on: < https://bityli.com/ VPjZ7>. Accessed on: Nov. 2018.

Barbosa Filho, J. A. D.; Queiroz, M. L. V.; Brasil, D. F.; Vieira, F. M. C.; Silva, I. J. O. Transport of broilers: Load microclimate during Brazilian summer. Engenharia Agrícola, v.34, p.405-412, 2014. https://doi.org/10.1590/S0100-69162014000300003

Cassuce, D. C.; Tinôco, I. F. F.; Baêta, F. C.; Zolnier, S.; Cecon, P. R.; Vieira, M. F. A. Thermal comfort temperature up date for broiler chickens up to 21 days of age. Engenharia Agricola, v.33, p.28-36, 2013. https://doi.org/10.1590/S0100-69162013000100004

Çengel, Y. A.; Boles M. A. Termodinâmica. 3.ed. Alfragide: McGrawHill de Portugal, 2001. 900p.

Garcia-Sanchez, A. J.; Garcia-Sanchez, F.; Garcia-Haro, J. Wireless sensor network deployment for integrating video-surveillance and data-monitoring in precision agriculture over distributed crops. Computers Electronics Agriculture, v.75, p.288-303, 2011. https://doi.org/10.1016/j.compag.2010.12.005

López-Martínez, J.; Blanco-Claraco, J. L.; Pérez-Alonso, J.; CallejónFerre A. J. Distributed network for measuring climatic parameters in heterogeneous environments: Application in a greenhouse. Computers and Electronics in Agriculture, v.145, p.105 - 121, 2018. https://doi.org/10.1016/j.compag.2017.12.028

Luan, Z. J.; Fan, H. L. Design and implementation of wireless sensor cellular network based on android platform. International Journal of Online Engineering, v.15, p.18-30, 2019. https://doi. org/10.3991/ijoe.v15i01.9774

Mujahid, A.; Furuse, M. Oxidative damage in different issues of neonatal chick sex posed to low environmental temperature. Comparative Biochemistry and Physiology Part A: Molecular and Integrative Physiology, v.152, p.604-608, 2009. https://doi. org/10.1016/j.cbpa.2009.01.011

Nazareno, A. C.; Silva, I. J. O.; Donofre A. C. Thermal gradients of container and mean surface temperature of broiler chicks transported on different shipments. Engenharia Agrícola, v.36, p.581-592, 2016. https://doi.org/10.1590/1809-4430-Eng.Agric. v36n4p581-592/2016
Nazareno, A. C.; Silva, I. J. O.; Vieira, F. M. C.; Santos, R. F. S. Temperature mapping of trucks transporting fertile eggs and dayold chicks: Efficiency and/or acclimatization? Revista Brasileira de Engenharia Agrícola e Ambiental, v.19, p.134-139, 2015a. https:// doi.org/10.1590/1807-1929/agriambi.v19n2p134-139

Nazareno, A. C.; Silva, I. J. O.; Vieira, F. M. C.; Santos, R. F. S. One dayold chicks transport: Assessment of thermal profile in a tropical region. Revista Brasileira de Engenharia Agrícola e Ambiental, v.19, p.663-667, 2015b. https://doi.org/10.1590/1807-1929/ agriambi.v19n7p663-667

Pautasso, C., Wild, E.; Alarco, R. Rest: Advanced Research Topic and Practical Applications. 1 ed. New York, Springer Science+Business Media, 2014. 222p. https://doi.org/10.1007/978-1-4614-9299-3

Quinn, A. D.; Baker, C. J. An investigation of the ventilation of a day-old chick transport vehicle. Journal of Wind Engineering and Industrial Aerodynamics, v.67, p.305-311, 1997. https://doi. org/10.1016/S0167-6105(97)00081-0

R4F Tecnologia Ltda. GS-100 controlador e Sismon 2014. Available on: <http://www.r4f.com.br/gs-100-concentrador/ >. Accessed on: Nov. 2018.

Rodrigues, V. C.; Silva, I. J. O.; Vieira, F. M. C.; Nascimento, S. T. A correct enthalpy relationship as thermal comfort index for livestock. International Journal of Biometeorology, v.55, p.455-45, 2011. https://doi.org/10.1007/s00484-010-0344-y

Ruiz-García, L.; Lunadei, L.; Barreiro, P.; Robla, J. I. A review of wireless sensor technologies and applications in agriculture and food industry: State of the art and current trends. Sensors, v.9, p.4728-4750, 2009. https://doi.org/10.3390/s90604728

SAS - Statistical Analysis System. Realease 9.2 (software). Cary: SAS Institute, 620p. 2010.

Schwartzkopf-Genswein, K. S.; Faucitano, L.; Dadgar, S.; Shand, P.; González, L. A.; Crowe, T. G.. Road transport of cattle, swine and poultry in North America and its impact on animal welfare, carcass and meat quality: A review. Meat Science, v.92, p.227-243, 2012. https://doi.org/10.1016/j.meatsci.2012.04.010

Souza, M. A.; Zambon, E. P.; Pinheiro, G. E. N. Tecnologia 3G como Determinante de Custos: Estudo em uma operadora de telefonia móvel. Contabilidade, Gestão e Governança, v.18, p.27-44, 2015.

Vieira, F. M. C; Groff, P. M.; Silva, I. J. O.; Nazareno, A. C.; Godoy, T. F.; Coutinho, L. L.; Vieira, A. M. C.; Silva-Miranda, K. O. Impact of exposure time to harsh environments on physiology, mortality, and thermal comfort of day-old chickens in a simulated condition of transport. International Journal of Biometeorology, v.63, p.1-9, 2019. https://doi.org/10.1007/s00484-019-01691-4

Vieira, F. M. C.; Silva, I. J. O.; Barbosa Filho, J. A. D.; Vieira, A. M. C; Broom, D. M. Pre slaughter mortality of broilers in relation to lairage and season in a subtropical climate. Poultry Science, v.90, p.2127-2133, 2011. https://doi.org/10.3382/ps.2010-01170

Vox, G.; Losito, P.; Valente, F.; Consoletti, R.; Scarascia-Mugnozza, G.; Schettini, E.; Marzocca, C.; Corsi, F. A wireless telecommunications network for real-time monitoring of greenhouse microclimate. Journal of Agricultural Engineering, v.237, p.70-79, 2014. https:// doi.org/10.4081/jae.2014.237 